\title{
COSTS OF PROVIDING LOCAL PUBLIC SERVICES AND COMPACT POPULATION IN SPANISH URBANISED AREAS
}

\begin{abstract}
This paper addresses the impact of land use patterns associated with compact population on the costs of provision and maintenance of urban public services for local entities, controlling for other factors. The aim is to develop an econometric analysis using a panel data set of municipalities of the Spanish Mediterranean area and Madrid in the period 2006-2014. The estimations derived from the study confirm one main hypothesis and indicate that compact population impacts positively on the decrease of municipal costs of urban public services. This study suggests that municipal planning instruments of local entities could contribute to efficiently manage their budgets, as well as orients public policy in terms of its local land use decision-making.
\end{abstract}

\section{Keywords}

Local public spending; compact population; panel data; Spain; Mediterranean.

\section{Introduction}

Sprawl and compact development have both costs and benefits, and no development pattern is optimal in all respects (Ewing and Hamidi, 2015). Nevertheless, it is expected that increasing urban sprawl and spatial processes of spread by decreasing the number of compact population higher provision and maintenance costs of public services, ceteris paribus the growth in number of inhabitants or revenues of local governments (Downing and Gusteley, 1977; Frank, 1989; Speir and Stephenson, 2002; Hortas-Rico and Solé-Ollé, 2010; Vallés and Zárate, 2011). In this sense, several local public services (water supply, sewerage and cleansing of waters or paving and lighting) have been shown to display economies of density in Spain (Prieto et al., 2015).

Here, the concept compact population is used to describe an aspect of the spatial pattern of urban development, and in particular whether such development is more or less compact, as concentration, one of the dimensions of land use patterns which describes the multidimensional process of urban sprawl (Galster et al., 2001).

The factors that has surely played some role in explaining the decreasing of compact population in Spain are: lower transportation costs with higher dependence on the private automobile and changes in gross domestic product (GDP) per capita (Ortuño-Padilla and Fernández-Aracil, 2013); socioeconomic dynamism and an increased accessibility by road (Molero et al., 2007); tourism and the lack of territorial planning (Grindlay et al., 2011); the filtering process of the urban land market (Catalan et al., 2008); as well as newer forms of mobility, expansionary policies of land development or housing typology specialisation of some municipalities, (Bellet and Gutiérrez, 2015). 
Therefore, sprawling cities are the opposite of compact cities, full of empty spaces that indicate the inefficiencies in development and highlight the consequences of uncontrolled growth (EEA, 2006). In terms of land take, Spain is in an outstanding position, compared to the rest of Europe (EEA, 2013) and, according to EEA (2006), Barcelona, Valencia, Murcia, Palma de Mallorca, Costa del Sol and Madrid are the most sprawled areas of Spain.

Moreover, according to Hennig et al. (2015), in terms of some indicators at NUTS-2 level such as weighted urban proliferation (WUP), which combines three components percentage of built-up area (PBA), the spatial distribution of built-up areas (DIS), and the land-uptake per person (LUP) in the built-up areas - and urban permeation of the landscape (UP), the most sprawled regions in Spain are the Mediterranean areas and Madrid.

Several studies have dealt with the sources of urban sprawl, but consequences have been less studied in the literature, where the empirical discussion of this nexus has usually focused on cross-sectional data in prior periods (Hortas-Rico and Solé-Ollé, 2010; Prieto et al., 2015) or some specific budgetary dynamic relationships founded (Hortas-Rico, 2014), and the current links between budgetary issues and compact population have not been sufficiently explored. For these reasons, it might be predicted that as compact population increases occur, detract from urban sprawl, the savings in the provision of public services also increase.

In recent years, governments have encountered the problem of ensuring suitable levels of productive investments while having to face serious budgetary restrictions; what is more, future recurrent costs of operation and maintenance should be taken into account when planning for new investment (Lara et al., 2011). In this regard, the "Ley 27/2013, de 27 de diciembre, de racionalización y sostenibilidad de la Administración Local" (27/2013 Act, dated 27 December, of rationalization and sustainability of local administration) establishes the concept "actual cost" of each individual provision of services, which implies the determination of a threshold on the basis of objectively quantifiable criteria and in accordance with the principle of sound management. The provision of local services has to be ensured at a price no greater than justified by the actual cost, which is determined by the mandatory and specific report.

Based on these notions, the present work addresses the impact of compact population on local budgets of Spanish municipalities, proposing an econometric panel data model, which includes a novel variable that can be used in order to measure the level of compact population in a municipality. The primary goal is to analyse the role of sprawled development models as determinants of local public spending by means of their opposite concept: urban compact development. The econometric model is estimated with reference to data for Spain's local administration sector from 2006 to 2014, analysing the main factors that have determined the costs of providing local public services in that period, and considering data at the municipality level for the Spanish provinces of Alicante, Almeria, Balearic Islands, Barcelona, Castellon, Girona, Granada, Madrid, Malaga, Murcia, Tarragona and Valencia (Mediterranean area and centre, see Figure 1).

\section{Materials and methods}

The analysis focuses on the 2006 to 2014 period, spanning a term of nine years, a time series with available homogeneous statistical data on municipal budgets and land use variables. The research concentrates on Mediterranean and central areas of Spain, which includes the provinces of Girona, Barcelona, Tarragona, Castellon, Valencia, Alicante, Murcia, Almeria, 
Granada, Malaga, Balearic Islands and Madrid (Figure 1). The municipality is considered the geographical unit of analysis because land use plans are determined at the municipal level and are embedded in large scale urban extensions.

The econometric analysis presented in this paper is based on the conceptual understanding of the theoretical base that combines cost and demand models (Borcheding and Deacon, 1972) which leads the variables choice, and also taking into account the context, the availability of data and the econometric principle of parsimony. This aspect allows us to differentiate the effects of the urban development model on local expenditure from those of other variables.

\section{Figure 1: area of study.}

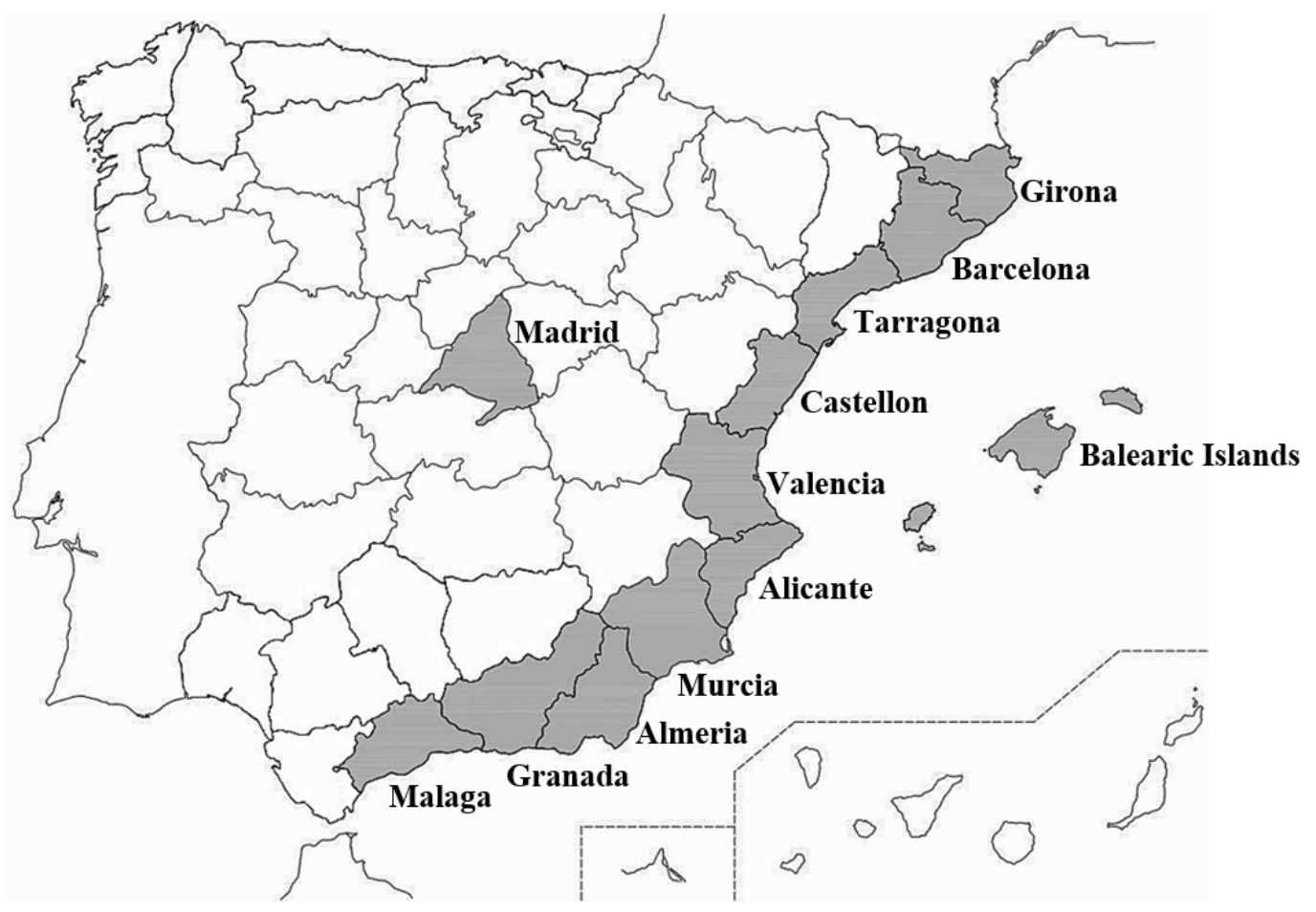

The dependent variable (EXPEN) is the expenditure on public services of local entities in the area of study. EXPEN is defined as the sum of expenditure subsections of: public safety, traffic management, urban planning, water supply, sewerage, waste management, street lighting, parks and gardens, energy, infrastructures, and public transport, among others. But structure which categorises public spending in sections of the liquidations of budgets of local entities is different in two periods of the span considered. The regulation of reference in year 2009 and before is "Orden de 20 de septiembre de 1989, por la que se establece la estructura de los presupuestos de las entidades locales" (Order issued by the Ministry of Economy and Finance, dated 20 September 1989, which establishes the structure of budgets of local entities); from 2010 onwards, "Orden EHA/3565/2008, de 3 de diciembre, por la que se aprueba la estructura de los presupuestos de las entidades locales" (Order issued by the Ministry of Economy and Finance/3565/2008, dated 3 December, which approves the structure of budgets of local entities) is the baseline: 
A. Sections of year 2009 and before are: public safety, production of goods of social interest, public goods for economic development and economic regulation of productive sectors.

B. Sections from 2010 onwards: spending on basic public services and measures for economic development.

The criteria for this selection of groups ensures the presence of a higher degree of similarity, because a greater number subgroups coincides; nevertheless, dummy variable DUM2 controls for differences between sub-periods of the above-mentioned groups of public expenditure.

As regards explanatory variables (Table 1), this model is similar to Carruthers and Ulfarsson (2003), but relies on a modified set of variables to reflect the significance of compact population. More specifically, per capita public expenditure in public services is regressed on (1) demographic and planning variables, including compact population size or population growth; (2) fiscal characteristics such as taxes, public rates and transfers, a structure dummy, and a dummy to controls for special intergovernmental revenues; and (3) a trend indicator combined with a recession dummy.

This is because a given public service is, especially, a function of the characteristics of the built environment and their population distribution (compact population and changes in demography) and revenues, including local taxes - direct, indirect and public rates - and intergovernmental sources - ordinary and capital transfers - (Carruthers and Ulfarsson, 2003). The two revenue groups are included in the analysis as the most locally assessed inputs, which represent, furthermore, most of the total revenue (Figure 2); but local bodies, actually, rely on different combinations of revenue sources: capital yields of properties, alienation sales, financial assets, etc.

Figure 2: evolution of revenues by sections of local entities in Spain (data for all municipalities in Spain), current prices in thousands of euros. Source: authors' analyses on the basis of Ministry of Finance and Public Authorities (Spain). 


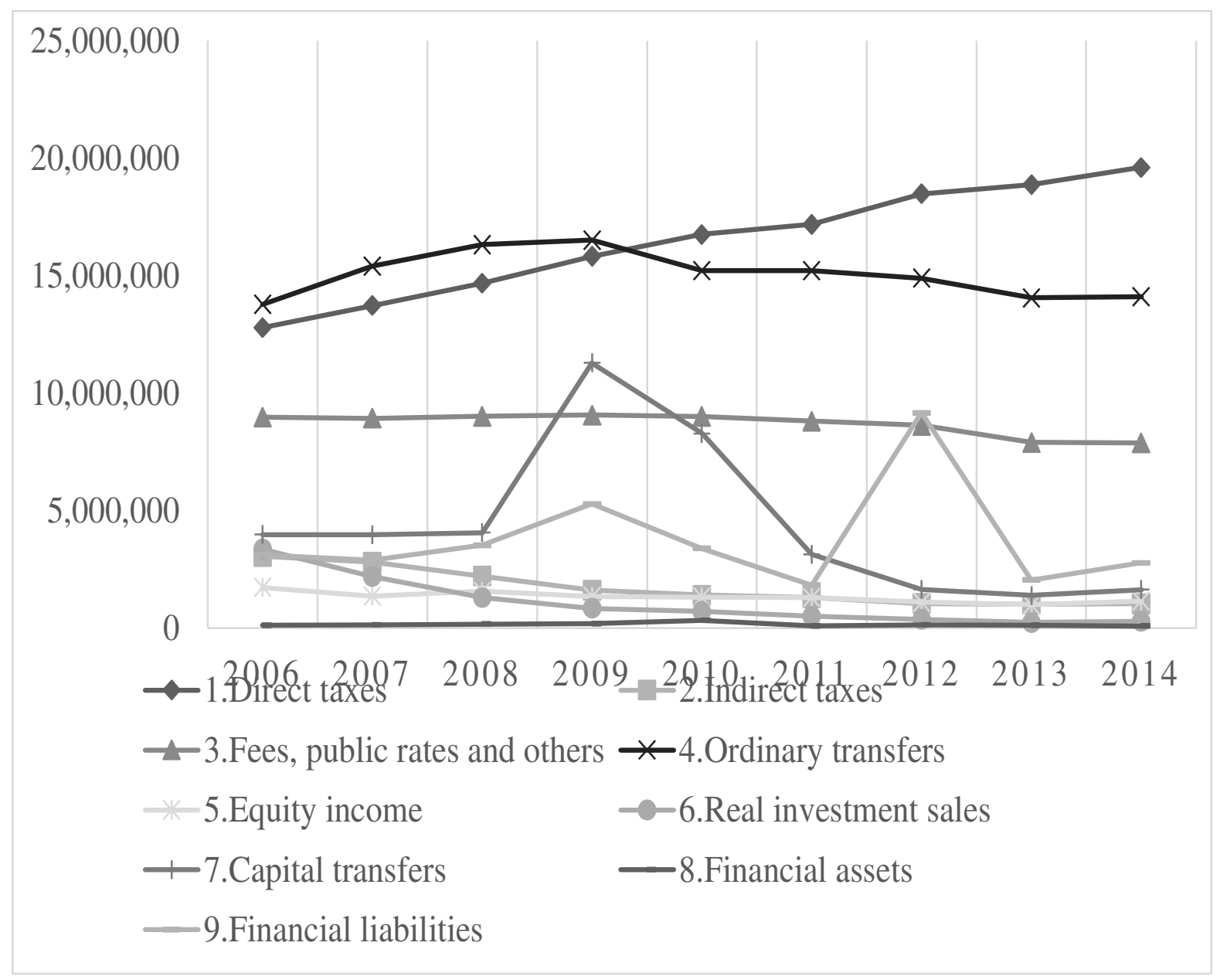

Sprawl and compact development represent two ends of a continuum of development types, characterized not only by density but by other variables (Ewing and Hamidi, 2015). Urban compactness is indicated here by compact population. These data were extracted by screening techniques on INE statistics called "Nomenclátor", according to the urban compactness model proposed by Goerlich and Cantarino (2013), as a quantitative metric to evaluate urban form.

Spain's National Statistical Institute (2016) provides a more comprehensive definition of spatial units in which Spain is divided, by focusing on the municipal register of inhabitants (Nomenclátor):

- Spain is divided administratively into autonomous communities, provinces, municipalities and other territorial local entities below municipal, whose delimitation, denomination, organisation and competences are described and regulated in detail in the legislation in force on local regimes.

- A population nucleus is considered to be a set of at least ten buildings that are made up of streets, squares and other urban roads. As an exception, the number of buildings will be less than 10, as long as the population that lives there exceeds 50 inhabitants. Included in the nucleus are those buildings that, being isolated, measure more than 200 metres from the exterior limits of the mentioned set while in the determination of 
the said distance the land occupied by industrial or commercial installations, parks, gardens, sports areas, cemeteries, car parks and others must be excluded as well as canals or rivers that may be crossed by bridges.

- The buildings or dwellings of a singular population entity that may not be included in the concept of a nucleus are considered as a scattered.

- According to Nomenclátor, a given municipality is divided into population nuclei and the scattered population.

Starting from that basis, the main independent variable is compact population in a given municipality, which is the number of inhabitants in a population nucleus, provided that the number is equal to or larger than 2,000 inhabitants in the reference year 2014. If a municipality has more than one population nucleus with 2,000 inhabitants and further, compact population is the sum of population of each nucleus.

The limit of 2,000 inhabitants might be the threshold beyond which a population will cease to be viable, in an economically efficient way - for instance, without economies of scale or economies of density (Prieto et al., 2015) - in terms of provision of public services. This figure reflects the choice of a simplified but measurable method based on the Goerlich and Cantarino (2013) theory — which addresses the concept urban area - , but empirically translated in conjunction with the European regulation on a public service which has standardised the lower limit of their efficient provision (EU, 1991) in order to choose the above-mentioned threshold: wastewater treatment.

Annual population growth, compared with the same period of previous year, is also included in the model because imposes fiscal burdens on established residents in the form of lower service levels (Ladd, 1992).

On the other hand, revenues of local entities had got the same structure to date, according to the "Texto Refundido de la Ley Reguladora de las Haciendas Locales (TRLRHL)" (Consolidated Text of the Law regulating Local Tax Authorities). However, an unusual element should be taken into account: the so called "Plan E", when, in 2009 and 2010, an increase in capital transfers (from central government) took place and new sources of financing were obtained by local entities. "Plan E" or "Plan Español para el estímulo de la Economía y el Empleo" (The Spanish Plan to Boost the Economy and Employment) aimed to stimulate national economy in collapse; consequently, 3,000 million euros were invested, although this initiative did not succeed. Dummy variable DUM1 controls for the influence of Plan E in the model.

The last independent variable included in the equation is TREND, which is the product of a crisis dummy multiplied by a time trend. The crisis dummy takes on the value " 1 ", for any crisis year and " 0 " otherwise. The period during which the crisis have occurred was limited to 2008-2013, because a given year has been considered into recession when the growth rate of gross domestic product has experienced negative sign during any trimester of the year.

Table 1: description and sources of independent variables.

\begin{tabular}{|l|l|l|l|}
\hline $\begin{array}{l}\text { Variable } \\
\text { abbreviation }\end{array}$ & Name (unit) & Description & Source \\
\hline
\end{tabular}




\begin{tabular}{|c|c|c|c|}
\hline $\begin{array}{l}\text { Variable } \\
\text { abbreviation }\end{array}$ & Name (unit) & Description & Source \\
\hline COMPA & $\begin{array}{l}\text { Compact } \\
\text { population } \\
\text { (inhabitants) }\end{array}$ & $\begin{array}{l}\text { Population which included in a } \\
\text { population nucleus, whose } \\
\text { number of resident inhabitants } \\
\text { is more than } 2,000 \text { in the } \\
\text { "Nomenclátor". }\end{array}$ & $\begin{array}{l}\text { National Institute of } \\
\text { Statistics (Spain), } 2016\end{array}$ \\
\hline INCRE & $\begin{array}{l}\text { Annual } \\
\text { population } \\
\text { growth }(\%)\end{array}$ & $\begin{array}{l}\text { Municipal growth rate of } \\
\text { population, compared to the } \\
\text { previous year. }\end{array}$ & $\begin{array}{l}\text { National Institute of } \\
\text { Statistics (Spain), } 2016\end{array}$ \\
\hline DIREC & $\begin{array}{l}\text { Direct taxes } \\
\text { (euros) }\end{array}$ & $\begin{array}{l}\text { Taxes whose taxable event are: } \\
\text { business, with legal or } \\
\text { economic nature, showing the } \\
\text { contributive capacity of the } \\
\text { taxpayer, such as the generation } \\
\text { of income coming from their } \\
\text { patrimony or rents. }\end{array}$ & $\begin{array}{l}\text { Ministry of Finance and } \\
\text { Public Authorities (Spain), } \\
2016\end{array}$ \\
\hline INDIR & $\begin{array}{l}\text { Indirect taxes } \\
\text { (euros) }\end{array}$ & $\begin{array}{l}\text { Taxes whose taxable event is } \\
\text { the consumption of taxpayers. }\end{array}$ & $\begin{array}{l}\text { Ministry of Finance and } \\
\text { Public Authorities (Spain), } \\
2016\end{array}$ \\
\hline RATES & $\begin{array}{l}\text { Fees, public } \\
\text { rates and } \\
\text { others (euros) }\end{array}$ & $\begin{array}{l}\text { Fees whose taxable event is } \\
\text { privative use, use of local } \\
\text { public domain or provision of } \\
\text { services. } \\
\text { Public rates are pecuniary } \\
\text { compensations with care } \\
\text { provided by services or by } \\
\text { activities under public law, } \\
\text { performed on the voluntary } \\
\text { application basis by the } \\
\text { administered. }\end{array}$ & $\begin{array}{l}\text { Ministry of Finance and } \\
\text { Public Authorities (Spain), } \\
2016\end{array}$ \\
\hline ORTRA & $\begin{array}{l}\text { Ordinary } \\
\text { transfers } \\
\text { (euros) }\end{array}$ & $\begin{array}{l}\text { Non tributary revenues, on a } \\
\text { free-of-charge basis, which are } \\
\text { intended to finance ordinary } \\
\text { transactions. }\end{array}$ & $\begin{array}{l}\text { Ministry of Finance and } \\
\text { Public Authorities (Spain), } \\
2016\end{array}$ \\
\hline CATRA & $\begin{array}{l}\text { Capital } \\
\text { transfers } \\
\text { (euros) }\end{array}$ & $\begin{array}{l}\text { Non tributary revenues, on a } \\
\text { free-of-charge basis, which are } \\
\text { intended to finance capital } \\
\text { transactions. }\end{array}$ & $\begin{array}{l}\text { Ministry of Finance and } \\
\text { Public Authorities (Spain), } \\
2016\end{array}$ \\
\hline DUM1 & Plan E & Dummy variable which takes & Ministry of Finance and \\
\hline
\end{tabular}




\begin{tabular}{|c|c|c|c|}
\hline $\begin{array}{l}\text { Variable } \\
\text { abbreviation }\end{array}$ & Name (unit) & Description & Source \\
\hline & (dummy) & $\begin{array}{l}\text { on the value } 1 \text { for each year } \\
\text { when local governments } \\
\text { received extra revenues from } \\
\text { central government. }\end{array}$ & $\begin{array}{l}\text { Public Authorities (Spain), } \\
2016\end{array}$ \\
\hline DUM2 & $\begin{array}{l}\text { Structure of } \\
\text { expenditure } \\
\text { sections } \\
\text { (dummy) }\end{array}$ & $\begin{array}{l}\text { Dummy variable which takes } \\
\text { on the value } 1 \text { for each year } \\
\text { when local budgets were } \\
\text { structured according to "Orden } \\
\text { de } 20 \text { de septiembre de 1989". }\end{array}$ & $\begin{array}{l}\text { Ministry of Finance and } \\
\text { Public Authorities (Spain), } \\
2016\end{array}$ \\
\hline TREND & $\begin{array}{l}\text { Trend and } \\
\text { recession }\end{array}$ & $\begin{array}{l}\text { Time trend variable from } 2006 \\
\text { to } 2014 \text { combined with a } \\
\text { recession dummy which takes } \\
\text { on the value } 1 \text { for each year } \\
\text { when Spain was considered } \\
\text { "currently in crisis" and } 0 \\
\text { otherwise. }\end{array}$ & $\begin{array}{l}\text { National Institute of } \\
\text { Statistics (Spain), } 2016\end{array}$ \\
\hline
\end{tabular}

Table 2 provides averages of variables at province level for the year 2014 and Table 3 provides summary statistics for all 1,918 municipalities evaluated. Focusing on Table 2, it should be borne in mind that Tarragona and Malaga actually have an additional municipality since 2011. The inclusion of both municipalities has not been possible because complete time series are not available.

Table 2: averages of some variables and pooled budgetary variables for the last year of study (2014).

\begin{tabular}{|l|r|r|r|l|l|l|}
\hline Provinces & \multicolumn{1}{|l|}{$\begin{array}{l}\text { Local } \\
\text { entities }\end{array}$} & $\begin{array}{l}\text { Compact } \\
\text { population } \\
\text { (inhabitants) }\end{array}$ & $\begin{array}{l}\text { Total } \\
\text { population } \\
\text { (inhabitants) }\end{array}$ & $\begin{array}{l}\text { Local } \\
\text { spending in } \\
\text { public } \\
\text { services } \mathbf{1 , 0 0 0} \\
\text { euros) }\end{array}$ & $\begin{array}{l}\text { Taxes, } \\
\text { fees and } \\
\text { public } \\
\text { rates } \\
\mathbf{( 1 , 0 0 0} \\
\text { euros) }\end{array}$ & $\begin{array}{l}\text { Ordinary and } \\
\text { capital } \\
\text { transfers } \\
\mathbf{( 1 , 0 0 0} \text { euros) }\end{array}$ \\
\hline Alicante & 141 & $1,553,466$ & $1,868,438$ & 741,638 & $1,170,301$ & 453,780 \\
\hline Almería & 102 & 547,542 & 701,688 & 278,776 & 387,565 & 247,054 \\
\hline Baleares & 67 & 887,051 & $1,103,442$ & 595,313 & 957,561 & 295,317 \\
\hline Barcelona & 311 & $5,045,150$ & $5,523,784$ & $3,106,584$ & $4,030,663$ & $2,494,296$ \\
\hline Castellón & 135 & 477,882 & 587,508 & 245,464 & 422,144 & 156,404 \\
\hline
\end{tabular}




\begin{tabular}{|l|r|r|r|l|l|l|}
\hline Provinces & \multicolumn{1}{|l|}{$\begin{array}{l}\text { Local } \\
\text { entities }\end{array}$} & $\begin{array}{l}\text { Compact } \\
\text { population } \\
\text { (inhabitants) }\end{array}$ & $\begin{array}{l}\text { Total } \\
\text { population } \\
\text { (inhabitants) }\end{array}$ & $\begin{array}{l}\text { Local } \\
\text { spending in } \\
\text { public } \\
\text { services } \mathbf{( 1 , 0 0 0} \\
\text { euros) }\end{array}$ & $\begin{array}{l}\text { Taxes, } \\
\text { fees and } \\
\text { public } \\
\text { rates } \\
\text { (1,000 } \\
\text { euros) }\end{array}$ & $\begin{array}{l}\text { Ordinary and } \\
\text { capital } \\
\text { transfers } \\
\mathbf{( 1 , 0 0 0} \text { euros) }\end{array}$ \\
\hline Girona & 221 & 548,337 & 756,156 & 431,055 & 678,938 & 259,583 \\
\hline Granada & 168 & 734,721 & 917,345 & 325,634 & 458,354 & 393,400 \\
\hline Madrid & 179 & $6,313,288$ & $6,454,440$ & $3,304,115$ & $5,110,001$ & $2,124,643$ \\
\hline Málaga & 100 & $1,431,060$ & $1,618,539$ & 831,374 & $1,343,507$ & 693,386 \\
\hline Murcia & 45 & $1,143,447$ & $1,466,818$ & 547,384 & 867,235 & 372,056 \\
\hline Tarragona & 183 & 609,592 & 795,155 & 398,473 & 678,075 & 276,334 \\
\hline Valencia & 266 & $2,294,972$ & $2,548,898$ & 902,372 & $1,400,603$ & 794,871 \\
\hline
\end{tabular}

Table 3: summary statistics for entire dataset, with 17,262 observations (constant terms).

\begin{tabular}{|l|r|r|r|r|}
\hline Variable (unit) & \multicolumn{1}{|l|}{ Mean } & \multicolumn{1}{l|}{ Std. Dev. } & \multicolumn{2}{l|}{ Max } \\
\hline EXPEN (euros) & 737.8 & 867.1 & 0 & 44895.3 \\
\hline COMPA (inhabitants) & $11,137.9$ & $88,376.1$ & 0 & $3,273,049.0$ \\
\hline INCRE (\%) & 1.0 & 4.5 & -38.3 & 82.2 \\
\hline DIREC (euros) & $5,353,630$ & $46,200,000$ & 0 & $2,290,000,000$ \\
\hline INDIR (euros) & $505,555.4$ & $4,782,488$ & 0 & $2,010,000,000$ \\
\hline RATES (euros) & $2,581,218$ & $22,000,000$ & 0 & $1,500,000,000$ \\
\hline ORTRA (euros) & $4,111,178$ & $40,800,000$ & 0 & $424,000,000$ \\
\hline CATRA (euros) & $1,018,822$ & $6,418,426$ & 0 & 1 \\
\hline DUM1 & 0.2 & 0.4 & 0 & 1 \\
\hline DUM2 & 0.4 & 0.5 & 0 & 1 \\
\hline TREND & 0.6 & 0.5 & \multirow{2}{*}{0} & 0 \\
\hline
\end{tabular}




\section{Calculation}

Revenue and cost variables are established in constant terms - real prices in euros of 2011 before the regression analysis, using the consumer price index (CPI) at provincial level (Spain's National Statistical Institute, 2016), which is their maximum level of disaggregation in Spanish statistics.

A reduced form log-log Equation (0) - using natural logarithm of the variables plus one, to deal with zero values - estimates the impact of the previous factors on public expenditure in public services and takes the following specification:

$\log \left(\mathrm{Y}_{\mathrm{it}}\right)=\beta \cdot \log \left(\mathrm{X}_{\mathrm{it}}\right)+\beta_{\mathrm{o}}+\varepsilon$

Where,

$\mathrm{Y}=$ costs per capita in provision and maintenance of public services

$\mathrm{X}=$ independent variables

$\beta_{\mathrm{o}}=$ constant

$\beta=$ vectors of regression coefficients

$\varepsilon=$ error term

$\mathrm{i}=$ municipality

$\mathrm{t}=$ year

The model could be estimated based on three possible methods used in panel regression: Generalized Least Squares (GLS), GLS with fixed effects or random effects. An important benefit from combining time-series and cross-section data is the ability to control for individual-specific effects-possibly unobservable-which may be correlated with other included variables in the specification of an economic relationship; analysis of cross-section data alone can neither identify nor control for such individual effect (Hausman and Taylor, 1981).

In order to choose a method, it should be first tested for the presence of individual effects using a Breusch-Pagan Lagrange multiplier test. If individual effects are found, it can be then studied the possibility of adding fixed or random effects. Fixed effects have the advantage of taking into account the particular characteristics of municipalities. However, they cause the loss of $\mathrm{N}-1$ degrees of freedom. Also, using fixed effects may make the estimation of the regression coefficients less efficient. For that reason, a model with random effects will provide more efficient estimates but should be used only if possible. The Hausman test evaluates the hypothesis that the coefficients estimated with random effects are the same as those estimated by fixed effects. When this hypothesis is confirmed, a model with random effects could be used (Wooldridge, 2002; Pérez, 2008).

\section{Results and discussion}


Regressions were done using Stata software and, as a result, it has been necessary to use the fixed effects model for the equation (Table 4). Figure 3 shows the partial correlations between expenditure and control variables after the econometric analysis.

$\log (\mathrm{EXPEN})_{\mathrm{it}}=\beta_{\mathrm{o}}+\beta_{1} \cdot \log (\mathrm{COMPA})_{\mathrm{it}}+\beta_{2} \cdot \mathrm{INCRE}_{\mathrm{it}}+\beta_{3} \cdot \log (\mathrm{DIREC})_{\mathrm{it}}+\beta_{4} \cdot \log ($ INDIR $) \mathrm{it}+$ $\beta_{5} \cdot \log (\text { RATES })_{\text {it }}+\beta_{6} \cdot \log (\text { ORTRA })_{\text {it }}+\beta_{7} \cdot \log (\text { CATRA })_{\text {it }}+\beta_{8} \cdot$ DUM $1+\beta_{9} \cdot$ DUM $2+$ $\beta_{10} \cdot$ TREND $+\varepsilon$

Table 4: estimation results of Equation 1 (t-statistics in parentheses).

\begin{tabular}{|c|c|}
\hline Independent variable & Coefficients \\
\hline $\log ($ COMPA $)$ & $-0.217 * *(-2.34)$ \\
\hline INCRE & $0.003 *(1.98)$ \\
\hline $\log (\mathrm{DIREC})$ & $0.059 * *(3.11)$ \\
\hline $\log ($ INDIR $)$ & $0.030 * *(6.37)$ \\
\hline $\log (\mathrm{RATES})$ & $0.171^{* *}(11.62)$ \\
\hline $\log ($ ORTRA $)$ & $0.216^{* *}(12.34)$ \\
\hline $\log (\mathrm{CATRA})$ & $0.048 * *(20.12)$ \\
\hline DUM1 & $0.205^{* *}(12.48)$ \\
\hline DUM2 & $0.653 * *(41.45)$ \\
\hline TREND & $-0.000(-0.08)$ \\
\hline CONSTANT & $-0.032(-0.09)$ \\
\hline $\mathrm{R}^{2}$ & 0.56 \\
\hline $\mathrm{F}(10,15334)$ & $3252.61 *$ \\
\hline Number of observations & 17,262 \\
\hline \multirow{3}{*}{ Breusch-Pagan test } & $\mathrm{H}_{0}: \operatorname{Var}(\mu)=0$ \\
\hline & Chi-square $(1)=13,211.57$ \\
\hline & Prob $>$ chi-square $=0.0000$ \\
\hline $\begin{array}{l}\text { Hausman test } \\
\text { A model with fixed effects could be }\end{array}$ & $\begin{array}{l}\mathrm{H}_{0} \text { : difference in coefficients not } \\
\text { systematic }\end{array}$ \\
\hline
\end{tabular}




\begin{tabular}{|l|l|}
\hline Independent variable & Coefficients \\
\hline used & Chi-square $(9)=217.13$ \\
\cline { 2 - 2 } & Prob $>$ Chi-square $=0.0000$ \\
\hline
\end{tabular}

The statistical significance is expressed through $* *=1 \%$ and $*=5 \%$.

Figure 3: correlation between local expenditure and control variables.
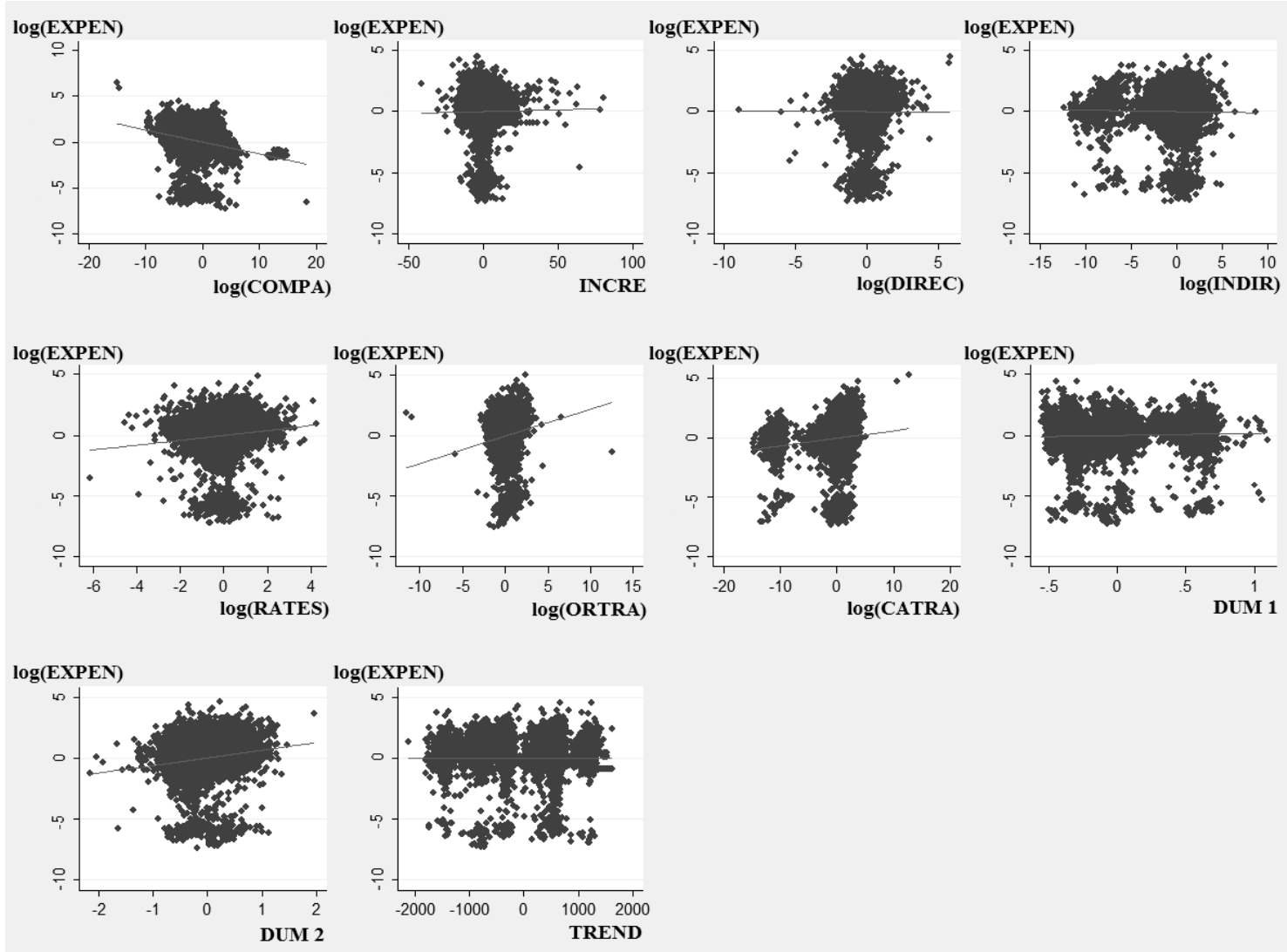

Regarding the previous results, we can confirm that compact population and local revenues more specifically fees, public rates and ordinary transfers - are influential factors (having a negative and positive impact, respectively) for the increase of the costs of provision and maintenance of public services.

All coefficients - excluding TREND - are statistically significant and all signs confirms our hypotheses, with a relatively high R-squared.

The coefficient of the variable related to compact population (COMPA) is negative and statistically significant. It reflects an appreciable capacity to decrease per capita costs on public services. On the other hand, population growth reveals a lesser positive impact.

According to the estimations, a $1 \%$ increase in compact population is associated with a 0.217 $\%$ per capita decrease in costs. In the same way, an increase of $1 \%$ of ordinary transfers and fees, generates $0.216 \%$ and $0.171 \%$ more spending in public services, respectively. 
Plan E and structure of budgets dummy variables show positive signs and they take into account two specific factors which influence costs of public services. Precisely, the presence of central government extra transfers, increases $0.205 \%$ public spending on urban services; besides, the difference between one budget structure period and another is determined increasing urban public services costs $0.653 \%$.

TREND is not statistically significant and this may be due to revenues of local government were not influenced by variations in the business cycle, because during the Spanish recession, losses of construction taxes - most of indirect taxes - were made up for direct taxes and the set remained almost without variation for the duration of the crisis period (Figure 2). This finding is consistent with the results obtained in Pérez-López et al. (2013).

Urban planning shapes land use mix, determines connectivity and accessibility to urban services, its attractiveness and their perceived value in the real estate market. Thus, household location preferences and private investor's decisions rely heavily on how municipal intervention is designed. Inversely, municipal decision-making for urban planning can create market distortions that - in a climate of propriety - inflict externalities (Fernández-Milán and Creutzig, 2016).

In Spain, property taxes or fees for the provision of local public services are defined in the municipal ordinances and the range of payable activities of each type of tax or fee is extremely diverse among municipal governments. For instance, in Alicante province, in a municipality called "A", fees for the service to collect solid waste are charged by differentiating between houses located in the urban core and those situated in the outskirts. On the other hand, in a municipality called "B", all citizens are subject to the same fee, and so on.

Continuing the same example above, in Alicante province, municipalities with a kind of tax discrimination, such as municipality "A", are nearly $15 \%$, which is a relatively small figure. In the case of the service to collect solid waste, Pay-As-You-Throw programmes may be the best alternative, which charge residents based on the number and sizes of trash containers or bags collected. Generally, residents in households, commercial or administrative buildings which consume a larger share of services according to their urban pattern, should have higher tax levels. Local authorities need to be conscious not only of the short-term implications of public investments regarding excessive development (which are already covered by indirect taxes), but of the long-term financial implications of their land-use decisions (Hortas-Rico, 2014), which may be covered by a restructured, discriminatory and homogeneous system of direct taxes. In addition, with a view to gradually implementing a strategy of internalising the external environmental costs, this discriminatory tax system could contribute.

\section{Conclusions}

This study has analysed the empirical relation between compact population and local governments spending on public services - controlling for other factors - in the municipalities of the Mediterranean area of Spain and Madrid, for the period 2006-2014. In general, the results provide evidence that the increase of compact population decreases cost of urban services, which prevents the resulting decline in socioeconomic efficiency and sustainability.

As a possibility, in order to remedy market failures which fosters sprawling development patterns, local governments could levy "impact fees" where developers are charged for the full cost of infrastructure (Brueckner and Kim, 2003) and increases in compact population 
were encouraged. In this regard, nowadays, municipalities of Spain scarcely include fiscal discrimination in respect of charges imposed on property tax or on fees for the provision of local public services, according to the existing urban pattern or populating model. For this reason, residents in households which consume a larger share of services - low density, reduced compact population, high sprawl - , should have higher tax levels.

On the other hand, alternatively, smart growth initiatives have had limited success to date, but government can foster more efficient transit-oriented development patterns by raising the cost of auto use, relaxing local regulations on land-use intensity and mix of land uses, and entering into partnerships with progressive developers (Ortuño, 2013; Ewing and Hamidi, 2015).

\section{Funding}

This work was supported by the Office of the Vice President of Research and Knowledge Transfer of the University of Alicante.

\section{References}

Bellet, C., Gutiérrez, A., 2015. Los efectos territoriales del crecimiento y la producción inmobiliaria en ciudades medias españolas. El caso de Lleida (1990-2012). In: Bellet, C., Melazzo, E.S., Sposito, M.E.B., Llop, J.M. (Eds.), Urbanización, producción y consumo en ciudades medias/intermedias. Edicions de la Universitat de Lleida, Lleida, 297-314.

Borcheding, T.E., Deacon, R.T., 1972. The demand for the services of non-federal governments. The American Economic Review 62 (5), 891-906.

Brueckner, J.K., Kim, H., 2003. Urban sprawl and the property tax. International Tax and Public Finance 10, 5-23, http://dx.doi.org/10.1023/A:1022260512147

Catalan, B., Saurí, D., Serra, P., 2008. Urban sprawl in the Mediterranean?: Patterns of growth and change in Barcelona Metropolitan Region 1993-2000. Landscape and Urban Planning 85 (3-4), 174-184, http://dx.doi.org/10.1016/j.landurbplan.2007.11.004

Carruthers, J.I., Ulfarsson, G.F., 2003. Urban sprawl and the cost of public services.

Environment and Planning B: Planning and Design 30, 503-522, http://dx.doi.org/10.1068/b12847

Downing, P.B., Gusteley, R.D., 1977. The public service costs of alternative development patterns: a review of the evidence. In: Downing, P.B. (Ed.), Local service pricing policies and their effect on urban spatial structure. University of British Columbia Press, Vancouver, 6386.

España, 1989. Orden, de 20 de septiembre de 1989, por la que se establece la estructura de los presupuestos de las entidades locales. Boletín Oficial del Estado, de 20 octubre de 1989, No 252, 33023-33039.

España, 2008. Orden EHA/3565/2008, de 3 de diciembre, por la que se aprueba la estructura de los presupuestos de las entidades locales. Boletín Oficial del Estado, de 10 de diciembre 2008, No 297, 49318-49362.

España, 2013. Ley 27/2013, de 27 de diciembre, de racionalización y sostenibilidad de la Administración Local. Boletín Oficial del Estado, de 30 de diciembre 2013, No 312, 106430 106473. 
European Environment Agency (EEA), 2006. Urban sprawl in Europe. European Commission DG-Joint Research Centre 10, 1-60.

European Environment Agency (EEA), 2013. Land take. European Commission, 1-21.

European Union, 1991. Council Directive 91/271/CEE, of 21 May 1991, concerning urban waste water treatment. Official Journal of the European Communities, 30 May 1991, No 135, 40-52.

Ewing, R., Hamidi, S., 2015. Compactness versus sprawl: a review of recent evidence from the United States. Journal of Planning Literature, 1-20,

http://dx.doi.org/10.1177/0885412215595439

Fernández-Milán, B., Creutzig, F., 2016. Municipal policies accelerated urban sprawl and public debts in Spain. Land Use Policy 54, 103-115,

http://dx.doi.org/10.1016/j.landusepol.2016.01.009

Frank, J.E., 1989. The cost of alternative development patterns: a review of the literature. Urban Land Institute, Washington, DC.

Galster, G., Hanson, R., Ratcliffe, M.R., Wolman, H., Coleman, S., Freihage, J., 2001. Wrestling sprawl to the ground: defining and measuring an elusive concept. Housing Policy Debate 12, 681-717, http://dx.doi.org/10.1080/10511482.2001.9521426

Goerlich, F.J., Cantarino, I., 2013. Zonas de morfología urbana. Fundación BBVA, Bilbao.

Grindlay, A.L., Zamorano, M., Rodríguez, M.I., Molero, E., Urrea, M.A., 2011.

Implementation of the European Water Framework Directive: Integration of hydrological and regional planning at the Segura River Basin, southeast Spain. Land Use Policy 28, 242-256, http://dx.doi.org/10.1016/j.landusepol.2010.06.005

Hausman, J.A., Taylor, W.E., 1981. Panel data and unobservable individual effects. Econometrica 49 (6), 1377-1398.

Hennig, E.I., Schwick, C., Soukup, T., Orlitová, E., Kienast, F., Jaeger, J.A.G., 2015. Multiscale analysis of urban sprawl in Europe: towards a European de-sprawling strategy. Land Use Policy 49, 483-498, http://dx.doi.org/10.1016/j.landusepol.2015.08.001

Hortas-Rico, M., Solé-Ollé, A., 2010. Does urban sprawl increase the costs of providing local public services? Evidence from Spanish municipalities. Urban Studies 47 (7), 1513-1540, http://dx.doi.org/10.1177/0042098009353620

Hortas-Rico, M., 2014. Urban sprawl and municipal budgets in Spain: A dynamic panel data analysis. Papers in Regional Science 93 (4), 843-864, http://dx.doi.org/10.1111/pirs.12022

Ladd, H.F., 1992. Population growth, density and the costs of providing public services. Urban Studies 29 (2), 273-295, http://dx.doi.org/10.1080/00420989220080321

Lara Galera, A.L., Sánchez Soliño, A., Balibrea Iniesta, J., 2011. La Colaboración PúblicoPrivada: fórmulas conocidas adaptadas a los nuevos tiempos. Revista de Obras Públicas 3,521, year 158, 43-54.

Ministry of Finance and Public Authorities, 2016. https://ssweb.seap.minhap.es (last accessed 10 April 2016). 
Molero-Melgarejo, E., Grindlay-Moreno, A.L. Asensio-Rodríguez, J.J., 2007. Escenarios de aptitud y modelización cartográfica del crecimiento urbano mediante técnicas de evaluación multicriterio. GeoFocus 7, 120-147.

National Institute of Statistics (Spain), 2016. http://www.ine.es (last accessed 10 April 2016).

Ortuño, A., 2013. El modelo "Transit-Oriented Development (TOD)". Posibilidades de implementación en el corredor Alicante-Benidorm. Revista Iberoamericana de urbanismo 10, 23-33.

Ortuño-Padilla, A., Fernández-Aracil, P., 2013. Impact of fuel price on the development of the urban sprawl in Spain. Journal of Transport Geography 33, 180-187,

http://dx.doi.org/10.1016/j.jtrangeo.2013.10.004

Pérez, C., 2008. Econometría avanzada: técnicas y herramientas. Pearson Prentice Hall, Madrid.

Pérez López, G., Plata Díaz, A.M., Zafra Gómez, J.L., López Hernández, A.M., 2013. Deuda viva municipal en un contexto de crisis económica: análisis de los factores determinantes y de las formas de gestión. Revista de Contabilidad - Spanish Accounting Review 16 (2), 83-93.

Prieto, A.M., Zofio, J.L., Álvarez, I., 2015. Cost economies, urban patterns and population density: the case of public infrastructure for basic utilities. Papers in Regional Science 94 (4), 795-816, http://dx.doi.org/10.1111/pirs.12096

Speir, C., Stephenson, K., 2002. Does sprawl costs us all?. Journal of the American Planning Association 68 (1), 56-70, http://dx.doi.org/10.1080/01944360208977191

Vallés, J., Zárate, A., 2011. Municipios de montaña y disparidades en las necesidades de financiación de los servicios públicos locales. Journal of Depopulation and Rural Development Studies 14, 7-34, http://dx.doi.org/10.4422/ager.2011.08

Wooldridge, J. M., 2002. Econometric analysis of cross section and panel data. MIT Press, Cambridge. 